Nordisk MuseOlogi 200I • I-2, S. 80-92

\title{
UR FYRA PLANDOKUMENT
}

John Aage Gjestrums 1990-tal dominerades av en febril aktivitet knuten till en rad skilda àtaganden och initiativ. De avspeglas främst i det tiotal 'plandokument' som förtecknas $i$ hans bibliografi. Ur fyra av dem àterges utdrag som kan ge en uppfattning om spännvidden i hans intressen och engagemang. Det första är hämtat ur en studie 1993 på uppdrag av de svenska kommunala museernas samarbetskommitté som fäste uppmärksambet på de svenska lokala museernas undanskymda tillvaro i museilandskapet. John Aage hävdade - vilket onekligen väckte uppseende - dels att den officiellt tillämpade museidefinitionen i Sverige på centrala punkter avvek frän ICOMs, dels att vare sig dessa museers existens eller verksamhet därför överhuvudtaget räknades. Det andra är hämtat ur en förstudie till ett informationscentrum för jugendstaden Alesund, utförd 1995 tillsammans med Marc Maure. Ar 1998 arbetade John Aage med förprojektet till en Antikvarisk Bygningsbank för "Østlandets flatbygd", varur ingressen àterges. Slutligen fäste utredningen 1999 om Kapps mjölkfabrik uppmärksambeten på en föga känd fas av jordbruksnäringens industrialisering.

\section{OM LOKALE/KOMMUNALE MUSEER I DET SVENSKE MUSEUMSBILDET}

Det er pr. idag ganske klart at ingen har presentert noen egentlig oversikt over tallet på museer i Sverige. Ingen kan sees å ha forsøkt engang på å lage en oversikt. Det burde være en viktig utredningsoppgave å få dette gjort.

Det er likevel ikke første gang dette påpekes. I 1986 skriver Margareta Sigurdson om lokalmuseene som 'En träffpunkt i lokalsamhället' i sitt bidrag till antologien Museiperspektiv som Statens kulturråd ga ut:
Bristen på begreppsapparat och terminologi är slående såväl för de lokala museerna som för museer i allmänhet. Överblick över lokala museer saknas. Centrala register över alla dessa museer borde vara något självklart som källa till kunskap i många sammanhang.

Når en 7 år etterpå leser Sigurdsons artikkel er det ihvertfall klart at årsaken til at ingen endring har skjedd i det statlige og offisielle synet på musei-Sverige ikke skyldes at en ikke har kjent svakhetene. Sigurdsons artikkel er klar og tydelig, og et like viktig bidrag i dagens diskusjon som det var i 1986, - men altså bevisst oversett...

Ved å sette sammen tre lett tilgjengelige kilder kan vi imidlertid nærme oss et mer full- 
stendig bilde av musei-Sverige, og kanskje gjøre det vi kan kalle en kvalifisert gjetning i retning av en tallfesting av museene:

1. SCB-statisikken for 1991 omhandler 210 museer, fordelt på 196 institusjoner i 106 kommuner (37\% av svenske kommuner).

2. Boka Museer $i$ Sverige (Bengt Nyström 1990) som omhandler 399 museer i 132 kommuner (46\% av svenska kommuner).

3. Boka Arbetets historia i Sverige (Jan af Geijerstam 1990)som omhandler 385 museer, samlinger og miljöer i 155 kommuner (55\% av svenske kommuner).

Nio museer er nevnt bare i SCB-statistikken, 107 museer er nevnt både i Nyström og Geijerstam. Dette gir en samlet sum på 686 museumstiltak og viser at det $i 194$ svenske kommuner er museumsvirksombet $(68 \%$ av kommunene). Fordelingen på den alminnelig brukte kommuneinndelingen viser følgende. I parentes for sammenligning er tallene fra SCB-statistikken for 1991.

28 glesbygdskommuner:

14 har museer, 50\% (SCB: 7=24\%)

36 landsbygdskommuner

17 har museer, $47 \%$ (SCB: $8=22 \%$ )

16 bruksorter

9 har museer, 56\% (SCB: 1=6\%)

100 normalkommuner

69 har museer, 69\% (SCB: 25=25\%)

38 mellanstora städer

36 har museer, $95 \%$ (SCB: $26=68 \%$ )

26 större städer

26 har museer, $100 \%$ (SCB:26=100\%)

36 förortskommuner

20 har museer, $56 \%$ (SCB: $10=28 \%$ )

3 storstadskommuner

3 har museer, $100 \%$ (SCB: $3=100 \%)$

Et uklart moment i en definering av svenske museer er hembygdsgårdene. Sveriges Hem- bygdsförbund kan ikke gi noen oversikt over hvordan de fordeler seg. Og det dreier seg om mange hundre (800?). I boka Museer i Sverige er det tatt med 10. I 1970 ble 45 tatt med i den landsdekkende museumsbesöksstatistikken. Ved bruk av disse dataene, og enkelte andre kilder som er lett tilgjengelige uten at en her kan gjøre noen grundigere studie av lokalmuseer og hembygdsgårder i de ulike len, kan vi legge til ytterligere 50 museer og 31 kommuner til listen over kommuner med museum. Vi kan da antyde et samlet tall for museer i Sverige på 736.

I den offisielle defineringen av museum i Sverige (Museiföreningen/SCB) legges det inn som kriterium at et museum skal ha minst et årsverk ansatt faglig personale, at det skal være åpent hele året, og dessuten være offentlig. Hva som menes med offentlig går ikke klart fram: offentlig eid?, offentlig finansiert?, ha tilsyn fra offentlig myndighet?, tilgjengelig for offentligheten?. Etter ICOMs museumsdefinisjon er det bare det siste av disse alternativer som er krevet, og en stor gruppe arbeidslivsmuseer og hembygdsgårder vil uten tvil være museer, - hvis de (1) har samlinger, (2) er tilgjengelige for publikum og (3) har en organisasjonsform der formålet er å bevare disse for framtida.

Fordelingen av Geijerstams museer og samlinger på kommuner viste at mens kommunetypen 'bruksorter' bare var representert med ett museum i SCBs statistikk (11\% av kommunene), økte tallet til 9 (56\%) i Geijerstams oversikt. Mens kommuner i gruppene 'glesbygd' og 'landsbygd' nå viser seg å ha lavest museumsdekning (henholdsvis 50\% og 53\%) er det svært sannsynlig at et grundigere arbeid med denne problemstillingen og derigjennom en gjennomgang av hembygdsgårdenes lokalisering og hvilke av dem som kan 
82 regnes som museer, vil føre til at nettopp langt flere av disse kommunene vil vise seg å ha museumsaktivitet.

En konklusion som kan trekkes ut fra dette er at det idag kan sies at det er museumsaktivitet i de aller fleste av Sveriges 284 kommuner (anslagsvis $80 \%$ av kommunene, ca 227 kommuner), og at denne aktiviteten fordeler seg på kanskje mer enn 700 ulike organiserte museumstiltak. I dette ligger også at $90 \%$ av alle svenske medborgere vil finne museumsaktiviteter/tilbud $i$ egen kommune.

Vi har (i ett annat avsnitt) foretatt en vurdering av et sannsynlig samlet besøkstall ved svenske museer, som vi anslår til nesten 50\% høyere enn dagens offisielle, og der dette ikkeregistrerte besöket foregår utenfor storstadsregionene. Fordelingen av et langt større antall museumsinstitusjoner over landet innebærer også at bildet av storstadsdominansen bør tones ned. SCBs statistikk viser at 52 av 210 museer (25\%) ligger i Stockholm, Göteborg, Malmö. Boka Museer i Sverige viser at 88 av 399 (22\%) museer er i disse 3 storstadskommunene. Ettersom museumstiltakene i disse 3 storstadskommunene er godt kjent, er det utover landet vi finner de aller fleste "nye" museene. En beregning gjort ut fra 736 museer viser at av disse er bare $12 \%$ i de 3 storstadskommunene, mens 648 (88\%) befinner seg utenfor. Setter vi dette oppmot SCB-statistikken, viser det at SCB har registrert nær $60 \%$ av museumstiltakene i storstäderna, men under $25 \%$ i landet forøvrig. Museene i de tre storstadskommmunene har istedet for mer enn halvparten av det totale besøkstall (slik SCB-statistikken har registrert), bare ca $1 / 3$ av museumsbesøket i landet.

Videre viser materialet at svært mange av de nye museumstiltakene, - bl.a. i form av arbeidslivsmuseer kommer i kommuner der det tidligere ikke var museer, f.eks. på bruksortene der informasjon om halvparten av museumstiltakene bare finnes i Geijerstams oversikt. For normalkommunene gjelder dette 22 kommuner og for førortskommunene 7 . Også når det gjelder gruppen mellomstore städer (38 kommuner) viser de "nye" tallene sterk økning. Det viktige ved dette er altså ikke bare det at vi viser at flere kommuner har museer, men at det over store deler av Sverige har vokst fram nye typer museer, som $i$ tema, sosial tilhørighet, formidlingsformer og vernefilosofi stair for en fornyelse og nyskapende virksombet innen det svenske museumsbildet.

Et utgangspunkt i dagens samfunnssituatsjon betyr at mange "gamle sannheter" har mistet sin gyldighet. De vekst- og utviklingsprognoser som har preget modernismen, og nådde sin høydepunkt på 1960- og 70-tallet, er nå på 1990-tallet avløst av det mange vil karakterisere som etterindustrielt samfunn, - den postmoderne tidsalder.

Etter en flere hundreårig tidsalder med framskrittsutvikling, er dette antakelig et langt mer dramatisk tidsskille enn vi umiddelbart kan oppfatte. Ikke minst ligger det større humanistiske utfordringer på menneskeheten, som skal å leve med etisk ansvar i ei tid da mennesket har alle muligheter til total ødeleggelse.

Noe av det mest spennende ved å være menneske, er nettopp dette å få være i nåtida, der det fortidige gjennom våre handlinger hele tida er under omskaping. Vi er i en livsform, en kultur, der også museer nå har inngått i flere generasjoner.

Sven B. Ek (i Idéforum museer, 1989) plasserer her lokalmuseene som en front $i$ verksambeten och att det är vid den fronten man arbetar med människorna. Det är där man tar 
tag i problemen och försöker behandla dem $p a$ ett vettigt sätt. Bak fronten, altså de som skal gjøre det virkelige arbeidet på feltet, ser Ek for seg visse støtteorgan, en omdannelse av det hierarkiske bildet som framkommer når det svenske museumsområdet beskrives.

En viktig museumsidé er knyttet til menneskers behov for å kjenne og forstå det sted der de kanskje tilbringer mesteparten av sitt arbeids- og sosiale liv. Bare ved slik forståelse kan enkeltmennesket ta stilling vis-à-vis fortida og de prosesser som har påvirket stedet og menneskene der. Ved å ta posisjon utvikles grunnlag for fellesskap og samhandling, for at menneskene kan bli aktører i verden, ikke bare tilskuere. I dette ligger viktige forutsetninger for våre demokratiske målsettinger.

Hjemstedet i det moderne industrisamfunnet har for mange først og fremst vært oppfattet som et sted stadig å reise fra. I tråd med målsettinger om optimal mobilitet. Det har derfor vært ønsket å knytte "irrasjonelle" følelser, nostalgi og romantikk til hjemstedet, mer enn empiri og faglige begrunnelser.

Det behov menneskene har for historisitet er noe annet enn vitenskapsmenns behov for å 'redde' kunnskapen om fortida. For forskeren er det viktige å finne ut ny kunnskap om historia, å se sammenhenger og oftest vektlegge det som er 'rikshistorisk' interessant. Den samme forskeren vil imidlertid kunne ha liten evne til å forstå at for enkeltmennesket, er det ikke akkumuleringen av ny historisk kunnskap som er verdifull, men etableringen av en historisitet, - av sjøl å være $i$ historia, i en sammenheng mellom det som var, det som er og det som skal bli.

Hvis vi i museene kan forholde oss til fortida som historikere, og være i nåtida som kulturarbeidere, hvilken rolle er vi i når og hvis vi forholder oss til framtida? Jean-Paul Sartre formulerer i sin eksistensialisme et perspektiv som er viktig for vår forståelse av museets og museumsarbeiderens rolle, når vi skal prove å svare på dette.

Menneskets eksistens er ikke statisk, - men blir hele tida til. Individet står i sammenheng med sin fortid, men er ikke absolut determinert av den. Dets tanker, valg og handlinger, - altså dets væren i nåtida, - bestemmes like mye av bevisstheten om framtidige muligheter. "Ifølge Sartre projekterer mennesket hele tiden sine framtidige eksistensmuligheter, ja $i$ en forstand 'er' mennesket disse mulighetene. ...Mennesket er nå ikke lenger det det har vært (i fortiden) og det er nå det det ennå ikke er (blitt i framtiden). Enklere: Mennesket er ikke sin fortid, det er sin mulige framtid" (Espen Schaanning, 1992).

Hva betyr dette for museet? Vi blir nødt til å akseptere museet som et humanistisk prosjekt. For humanisme innebærer vel nettopp denne muligheten, denne friheten til handling. Handlingene her kan være nettopp utvalget av hva fra fortiden som skal gjøres talende i museet, - det kan være å engasjere seg i viktige miljøspørsmål, - det kan være å velge å la alt være eksakt slik det har vært...

Uansett hvilket valg vi tar, så skjer det som et valg, der det eksisterer reelle friheter til å velge annerledes. I dette ligger en etisk utfordring for alle som arbeider med museer. Dette påvirker museets funksjon i nåtida, det påvirker framstillingen av fortida, og det er en del av samfunnets omforming. Kort sagt, museet kan ikke gjemme seg unna sin politiske funksjon.

- Ur en förstudie för Kommunala Museers Samarbetsråd 1993. 
Alle norske byer ble utsatt for storbranner i løpet av siste halvdel av forrige århundre, og med tildels svært omfattende dimensjoner. Størst var bybrannene i Drammen (1870) og Kristiansand (1892). Bybrannen i Ålesund i 1904 ble den aller største i Norgeshistorien. Natt til 23. Januar 1904 ble sentrumsbebyggelsen så godt som totalt utslettet: ca. 800 bygninger brant ned og 12.000 mennesker ble husløse. Bare brannen i Bergen (1916) ble større, men det skyldtes omfanget av verdiene som gikk tapt, mer enn antall hus som brant. Hyppighet og omfang av storbranner avtok fra 1910-åra, noe som i hovedsak skyldtes innføringen av Murtvangloven (1904).

Ålesund kom tidlig inn i en industrialiseringsprosess med modernisering av næringslivet. Byen var preget av omfattende økonomisk ekspansjon basert på fiskeressursene, med stor befolkningsvekst fra slutten av 1860-åra. Byen hadde 1.300 innbyggere da den fikk bystatus i 1848, mens befolkningstallet hadde økt til 12.000 i 1900 . Bebyggelsens struktur ble fortettet og nye områder tatt i bruk. Den nye bebyggelsen som reiste seg på Aspøya var et godt eksempel på det med et mer rettlinjet gatenett enn i det eldre sentrum. En romantisk bypark ble anlagt etter engelsk mønster.

Framvekst av en dynamisk og foretakslystent borgerskap var knyttet til byens økonomiske ekspansjon i århundrets siste halvdel. De store kjøpmennene var mektige; de dominerte byens økonomiske, sosiale og kulturelle liv. De spilte en avgjørende rolle også under byens gjenreisning etter brannen, både økonomisk og organisatorisk, og ikke minst i spørsmålene knyttet til byens utforming.

Valget av jugendstilen som dominerende arkitektonisk formspråk er det nærliggende å se nettopp i sammenheng med denne gruppens smak og behov. Det er vanskelig å tro at bruken av jugendstilen hadde vært så dominerende $\mathrm{i}$ byen uten de mektige borgernes samtykke. De sto selv som byggeherrer og oppdragsgivere for arkitektene, for reising av de mest gjennomførte og oppsiktsvekkende jugendbyggene i byen - Rønnebergbua, Stafsethgården, Apotekergården o.a.

Dette er helt i tråd med det som i samme periode skjer i andre jugendbyer i Europa. Et felles kjennetegn ved Art Nouveau/jugendarkitektur internasjonalt er at stilen sjelden ble valgt til utforming av offentlige oppdrag, der i stedet historismen ble foretrukket som formspråk. Det var representanter fra det nye og mektige borgerskapet, vokst fram i kjølvannet av industrialismens ekspansjon, som svært ofte var oppdragsgivere og brukte den nye stilen for å uttrykke sin makt og modernitet. Det er en uløselig del av jugendstil/Art Nouveau som sosialt og kulturelt fenomen i europeisk sammenheng, og gjelder også fullt ut for Ålesund.

Ålesund ble gjenreist i en spesielt betydningsfull historisk periode, - samtidig som Norge oppnår sin nasjonale selvstendighet. Dette ga bybrannen og gjenreisningen en sterk nasjonal symbolsk betydning. Det som skjedde i Ålesund ble en metafor for det som samtidig skjedde med Norge. Det gamle Ålesund brant ned og det nye Ålesund gjenoppstod som fuglen Fønix fra askene, på samme måte som det gamle Norge døde og det nye ble født.

Slutten av det forrige århundret var sterkt preget av arbeidet med å utvikle en norsk nasjonal kultur innenfor alle områder. Det gjaldt bl.a. arkitekturen, der dragestilen var 
svaret for trearkitekturen på behovet for å skape en egen norsk byggeskikk. Det eksisterte også et sterkt ønske om å skape en tilsvarende egen nasjonal arkitektur i stein, med røtter i byggetradisjoner fra den stolte og England/ Normandie-orienterte norske middelalderen. Ålesunds gjenreisning skulle gi mulighetene til å realisere dette programmet i stor skala.

I perioden 1904-07 signerte omkring 50 ulike arkitekter tegninger i Ålesund for nye murhus. Geografisk sett representerte de en stor bredde. De kom fra forskjellige byer i landet. Mange hadde dessuten hatt oppdrag på flere steder i Norge og flere i utlandet. Det var ei gruppe av unge arkitekter; i 1904 var den eldste 55 år, den yngste 25 år og ca. halvparten var yngre enn 35 år. En hovedandel hadde fagutdanning på høyeste nivå med en kombinasjon av norsk basisutdanning og utenlandsk videreutdanning, særlig fra Tyskland.

Verdsettingen av jugendstilen de seinere år har nær sammenheng med det arbeid Unesco har stått i spissen for siden 1985-86, da de første ekspertmøtene i Unesco-regi omkring jugendarkitekturen fant sted. I Unesco-konteksten er så Art Nouveau/jugendstil etablert som et pilotprosjekt for vern av det 20. århundredets arkitektur. Ekspertkomitéen hade sitt første møte i 1987, og da lagt nettopp til Ålesund. Komitéen avslutter sit arbeid i 1994 med Torino-deklarasjonen, som definerer kriterier for hva Art Nouveau-arkitektur er og for vern av denne arkitekturen.

I etableringen av Jugendsenteret i Ålesund er det nødvendig å vektlegge at Ålesunds bygningsmiljø ikke bare representerer et viktig bevaringsprosjekt, men først og fremst er et uttrykk for en spesiell holdning til arkitektur og byforming. Den oppmerksomhet gjenreisningen av Ålesund fikk etter brannen, der en lang rekke av landets fremste arkitekter deltok i utformingen av den nye byen og med jugendstilen som uttrykk, skapte en bybebyggelse av helt unik karakter.

Særpreget for Jugendsenteret vil bli skapt ved det helt spesielle samspillet mellom senteret som et tungt faglig kompetanse- og informasjonssenter og jugendarkitekturens enkeltobjekter og miljøer i Ålesunds bysentrum. Ålesund rommer så mange estetisk spennende objekter, med et i sum så stort samlet volum, at det er dette som bærer prosjektet. Jugendsenteret har imidlertid en nødvendig oppgave i det å skape mening - i å tydeliggjøre og forklare - ikke minst vil institusjonen bli viktig i det å hjelpe den enkelte huseier til å se sin oppgave innenfor den større helhet.

Forståelse blir derfor et viktig stikkord for det som skal være Jugendsenterets endelige produkt. Uten at denne forståelsen blir etablert hos alle aktører $\mathrm{i}$ byen vil det på lang sikt neppe være mulig å bevare jugendarkitekturen i Ålesund. Å formidle en slik forståelse - tydeliggjøre mening - til byens besøkende vil være en annen hovedoppgave, og en virksomhet som vil gi de mange besøkende en større opplevelse. At dette i neste omgang vil virke som en svært positiv faktor på turisme og reiselivsnæring, og derved styrke næringsfunksjonene i bykjernen som helhet, bør det nesten være unødvendig å peke på.

Av de ca. 350 bygningene reist etter brannen innenfor murtvangområdet, er det pr. idag mer enn 300 igjen. Selv om det opprinnelige bybildet er blitt vesentlig endret, er samtidig et omfattende og helt miljø bevart. Jugend- 
86 bebyggelse er etterhvert blitt byens stolthet, statussymbol og et felleseie. Dette kom da også tydelig fram i 1997 da to bygninger tilslutt ble revet, etter en lang og opprivende debatt om saken både lokalt og nasjonalt. Selv om bevaringsinteressene her tapt mot et nybyggingsprosjekt til 60 mill. kr., ble dette også en seier, ettersom utgangspunktet for utbyggerne var at 5 gjenreisningsbygninger skulle rives. Situasjonen som oppstod fokuserte på Ålesunds spesielle kvaliteter, og bevisstheten om dette har fătt sterkt feste både lokalt og nasjonalt. Samtidig viste hendelsene i 1997 at det er et stort behov for informasjon og kunnskapsformidling nettopp av den type Jugendsenteret skal stå for.

Jugendbyens betydning er ikke bare av arkitekturhistorisk karakter. Spørsmålet om estetikkens betydning for en befolknings bo-, arbeids- og oppvekstmiljö, er idag et sentralt debattema. Ålesunds jugendbebyggelse representerer offentlige rom med kunstneriske kvaliteter som har potensiale også til å være en viktig inspirasjonskilde for aktørene i byformingsprosesser i vår egen tid. Det skyldes Ålesunds estetiske og miljømessige kvaliteter: - byen som et definert sted, samlet og tett (kontra byen som åpent og glissent sted) - små dimensjoner og menneskelig skala (kontra undertrykkende og fremmedgjørende arkitektur)

- det uregelmessige, uoversiktelige og derfor spennende (kontra det rettlinjede og monotone)

- formrikdom og variasjon, frodighet i dekor og ornamentik (kontra formspråk kjennetegnet ved asketisme, ensformighet, stimulusfattigdom, karakterløshet)

- håndverk (kontra maskinproduserte og prefabrikerte elementer)
- blandingsfunksjoner med mangfold av hendelser og variert sosial struktur (kontra sonedeling og ensidig funksjonsbruk)

Den faglige virksomheten til Jugendsenteret vil her bli beskrevet i fire hoveddeler:

A: Formidlingstilbud.

Jugendsenteret skal arbeide med informasjon, kunnskapsformidling og holdningsskapende virksomhet rettet mot et bredt publikum, sammensatt av ulike grupper med forskjellige behov og forventninger:

- den spesialiserte bruker som bevisst søker informasjon utfra spesifikt behov om fordypning og oppdatering av kunnskap.

- den interesserte bruker som oppsøker senteret utfra generell interesse for institusjonens arbeidsfelt $\mathrm{og}$ for å få bredere insikt.

- den allmenne bruker som besøker senteret i sin fritid, for å finne generell informasjon, avkobling og opplevelse.

B. Dokumentasjonsvirksomhet.

For Jugendsenteret som kunnskapsinstitusjon innenfor sitt felt vil det bli en viktig oppgave å organisere og studere ulike typer informasjonsmateriale om gjenreisningsbebyggelsen i Ålesund. Dette er en virksomhet som bør bygges på en systematisk, problem- og prosjektorientert strategi. Jugendsenterets dokumentasjonsvirksomhet knyttet til jugendarkitektur vil videre innebære følgende hoveddimensjoner:

- Først knyttet til Ålesund - det spesielle eksempel med den store konsentrasjon av jugendbebyggelse: Hvorfor fikk jugendstilen en slik dominerende plass i byen? Det må gradvis gjøres konkret dokumentasjon om hvert eneste objekt. Det innebærer også dokumentasjon av elementer utover det arkitektoniske 
ytre, som innredning, møblering og dekor.

- Deretter knyttet til det nasjonale nivå med oppbygging av kunnskap om jugendarkitektur $\mathrm{i}$ andre norske byer. Ved at en på et sted får en samlet dokumentasjon vil ny kunnskap kunne etableres, bl.a. i de ulike arkitekters produksjon.

- Den tredje, men ikke minst viktige dimensjon er knyttet til det internasjonale niva: Jugendsenteret vil som nasjonal institusjon presentere norsk jugendarkitektur internasjonalt - og samtidig bygge opp en så omfattende dokumentasjon som mulig om Art Nouveau/ jugendstil $\mathrm{i}$ andre land. Internett-samarbeid med sentrale europeiske jugendbyer skal utgjøre et viktig element i sammenstillingen og tilgjengliggøringen av denne dokumentasjon.

C. Kompetanseoppbygging murhåndverk. Det er idag et stort misforhold mellom den kunnskap som er utviklet i Norge omkring bygging i tre og bygging i mur. Dette henger sammen med hvordan norsk arkitektur tradisjonelt har vært dominert av tre som byggemateriale. I eldre tid ble stein og mur bare brukt i helt spesielle sammanhenger, og da først og fremst i kirker, militære anlegg og andre offentlige bygninger.

Opp mot et nytt århundreskifte er det imidlertid nå tydelig at en stadig større del av arkitekturen som inngår i verneplaner og skal sikres for framtida, er bygget i mur - bl.a. nettopp fordi bebyggelsen er i bymiljøer der Ålesund-brannen i 1904 ga mer restriktive påbud om bruk av mur.

For norsk trebebyggelse er det i lang tid arbeidet aktivt med forskning og kunnskapsformidling omkring alle sider ved både håndverksteknikker, materialbruk og konserveringsprinsipper. Det betyr at det finnes både godt utviklede vitenskapelige fagmiljøer, or- ganiserte opplæringstiltak og utøvere av praktiske håndverksferdigheter.

Ålesunds store kvaliteter som murhusbebyggelse gjør det attraktivt å legge aktiviteter på nasjonalt plan rettet mot kompetanseoppbygging innenfor murhåndverk hit.

D. Internasjonalt nettverk.

Art Nouveau/jugendstil-bevegelsen var i sin natur et europeiske fenomen. Et hovedkjennetegn var en aktiv og omfattende spredning av idéer og produkter på tvers av landegrensene, og av enkelte byers dominerende plass $\mathrm{i}$ bevegelsen.

Internasjonalt har stilen lenge vært glemt og misforstått, og byggene utsatt for forsømmelse og riving. Men nå er jugendstilen blitt objekt for en omfattende interesse som aktualiserer et behov for kontakt og samarbeid over landegrensene.

For Ålesund vil kontakt og samarbeid med fagmiljøer i andre land bety mulighet til økt forståelse av byens egenart som jugendby. Samtidig vil fokus på Ålesund-bebyggelsen representere et nytt perspektiv i Art Nouveau/ jugendstil-forskningen internasjonalt, - en forskning som hittil har lagt hovedvekt på unike og isolerte verk fra de mest kjente arkitektene.

Kontakt og samarbeid med de europeiske jugendbyene vil i tillegg ha konsekvenser på andre felt, f.eks. som virkemiddel for profilering av Ålesund i det internasjonale reiselivsmarkedet. Dette samarbeidet vil dessuten kunne foregå utfra bredere perspektiver, av både kulturell og økonomisk karakter, som ledd i de strategier som idag kjennetegner den europeiske integrasjonsprosessen.

- Ur Jugendsenteret - en nasjonal institusjon. Ved J.A.G. og Marc Maure. Ålesund 1997. 
EN ANTIKVARISK

\section{BYGNINGSBANK}

Hvis du idag anskaffer en bil fra 1951, vil du gjøre dette uten noe ubehag knyttet til mulighetene for å skaffe nødvendige deler til motor, dekk, bremser osv. Ubehaget er evt. at en slik bil er forholdsvis dyr å anskaffe, og kanskje heller ikke så komfortabel å kjøre. Men opp gjennom årene har det skjedd en tilpasning mellom et spesielt marked og dets behov for spesielle produkter. Derfor er det en ganske kurant sak å eie en veteranbil, - og dessuten ganske morsomt.

Av grunner som ikke kan forklares her, har det ikke skjedd den samme grad av tilpasning mellom tilbud og etterspørsel når det gjelder det behov eiere av eldre hus har for produkter til istandsetting, vedlikehold og restaurering. Mens ingen en gang ville tenke tanken på å sette en ny Toyota-skjerm på en 1930modell A-Ford, skjer dette hele tida på gamle ærverdige hus omkring oss. Originale, profilerte paneler blir erstattet av "brutal" tømmermannspanel med harde kanter, og fint inndelte og omrammede vinduer i sveitser- eller jugendstil blir erstattet med husmorsvinduenes gapende hull i fasaden.

Selv på biler som sannsynligvis skal skrotes om bare 7-8 år passer eierne karosseriets overflate mot enhver minste rip eller bulk. Og dette er en investering som innen kort tid skal nedskrives til 0 . Et hus derimot representerer kanskje bortimot en million i verdi og skal stå i landskapet i generasjoner. Det ser ikke ut til å hindre eierne fra om og om igjen å velge de simpleste løsninger. Mens en ikke vil tenke tanken på å kjøre bil med en upassende skjerm, kanskje kr. 3000,- billigere enn "originalen", er en overlykkelig om en kan spare en tusenlapp på å sette et vindu inn i huset som "nesten" passer vegåpningen etter det gamle. En fyller bare i $20 \mathrm{~cm}$ under og tar ut $20 \mathrm{~cm}$ breiere åpning, og vips...(!)

Virkelighetsbeskrivelsen ovenfor kan sees som satt på spissen. Samtidig peker den mot noe av det som er hovedproblemstillingen for etableringen av en Antikvarisk bygningsbank for flatbygdsområdet på Østlandet: det er behov for en aktiv synliggjøring både av verdiene som ligger $\mathrm{i}$ riktig håndtering $\mathrm{av}$ den eldre bygningsmasse, og ikke minst er det behov for aktive tiltak som kan skape kontakt mellom et mulig tilbud og et mulig marked for produkter og tjenester.

Denne utredningen viser at det finnes et stort tilbud fra en lang rekke leverandører av tjenester. I regionen vi retter oss mot er det antakeligvis også mer enn 100.000 huseiere med bygninger som er eldre enn 100 år - og et langt større tall hvis vi også inkluderer en vesentlig del av bygningene bygd i tiårene oppover på 1900-tallet, bygninger som også er i stor fare for å bli maltraktert.

Bygningsmiljøet i landsbygd, tettesteder og byer skal i prinsippet ivaretas gjennom et godt utbygd regelverk i plan- og bygningslov, forvaltet av den enkelte kommunes bygningsetat. Praksis viser likevel at den formelle apparat synes å ha bare svært begrenset innflytelse over hva som skjer med den eksisterende bebyggelse. Den enkelte huseier synes å være fanget i de store byggevarehusenes standardiserte og storindustribaserte byggevareutvalg, tilpasset dagens moter innenfor nybygging. Dette fører til at mange føler seg maktesløse overfor oppgaven knyttet til å istandsette et eldre hus, og istedet river det for å bygge nytt. Eller at de forsøker å få det gamle huset til å "bli nytt" ved bruk av nye bygningsmaterialer. 
Mulighetene som ligger i gjenbruk av gamle bygningsmaterialer - som fortsatt vil være både funksjonsdyktige og estetisk overlegne - blir ikke synlige i dagens situasjon. Alle de mindre spesialleverandørene av produkter og tjenester er heller ikke synlige fordi de hver for seg er ganske små i markedet.

Agenda 21 er tittelen på sluttdokumentet fra FNs toppmøte om miljø og utvikling i Rio 1992. Dokumentet peker ut veier framover inn i det 21. århundre med løsningen på verdens miljøproblemer. Norge har undertegnet dokumentet. Et hovedperspektiv her er at det er behov for radikale endringer i de rike lands forbruksmønster dersom miljøproblemene skal kunne håndteres. I motsetning til de fleste slike avtaler med nasjonalstatene som aktører, vektlegger Agenda 21 betydningen av handling også på de lokale/kommunale nivåer i forvaltningen. Dokumentet peker faktisk på at det er på dette nivået en har kunne se konkrete resultater. Slagordet "tenke globalt, handle lokalt" poengteres, og: "Fordi de står menneskene nærmest, spiller lokale myndigheter en avgjørende rolle når det gjelder å opplyse, mobilisere og fange opp befolkningens ønsker $\mathrm{i}$ arbeidet med å fremme en bærekraftig utvikling", sies det i avsnitt 28 i Agenda 21. Og videre:

Alle lokale myndigheter bør gå inn i en dialog med innbyggerne, lokale organisasjoner og private bedrifter og vedta en "Lokal Agenda 21". Gjennom samråd med sikte på å skape konsensus, vil de lokale myndighetene lære av befolkningen og av de lokale frivillige organisasjoner, beboergrupper, bedrifter og fagforeninger og tillegne seg den kunnskapen som trengs for å utvikle best mulige strategier. Samrådsprosessen bør øke husholdningenes bevissthet om spørsmål som angår bærekraftig utvikling.
Mens mye av aktiviteten ikke minst på bygningsfeltet de siste to-tre tiår har vært preget av teknokratiske og kortsiktige perspektiv peker Lokal Agenda 21 på nødvendigheten av tidsperspektiver på 50-100 år - til nå nærmest ukjent i alminnelig lokal planlegging. En peker også på nødvendigheten av å knytte sammen miljøtenkningen med tenkning omkring livskvalitet. I dette perspektivet er den historiske bygningsarven nettopp én av faktorene som gjennom å gi historisk dybde i menneskenes daglige livsrom, nettopp vil kunne øke folks livskvalitet.

Et av de politiske konkretiseringer av målsettingene fra Rio-konferensen i Norge er St.meld. 58 Miljøvernpolitikk for en barekraftig utvikling (1996-97). Et av områdene som umiddelbart kommer i søkelyset når en skal nå lenger i utviklingen av et økologisk bærekraftig samfunn er bruk og ombruk av eldre bygninger, bygningsdeler og materialer.

Gjennom nye byggherreforskrifter er det kommet helt nye krav til byggeherrer og entreprenører som gjør oppføring, rehabilitering eller riving av bygninger. Byggherren er pålagt å utarbeide en plan for avfallshåndtering, og i miljøvernperspektiv er det en overordnet oppgave å minske avfallsmengden fra bygg/ anleggsvirksomhet. Faktisk representerer detta avfallet i Norge 1,2 mill. tonn pr. år, like mye som den samlede avfallsmengde fra norske husholdninger. Beregninger som er gjort viser at bare ca. $8 \%$ av bygningsavfallet går til ombruk og gjenvinning $i$ en eller annan form.

- Ur forprosjekt 1998. 


\section{Fra "Syltet" MELK TIL VIKING-MELK}

Historien om Kapp Melkefabrikk fra de første spadestikk høsten 1889 og fram til idag 110 år etterpå, er selvsagt ei historie om produksjon av melkeprodukter, tekniske produksjonsmåter og framveksten av en industriog arbeiderkultur i en kommune som til da hadde vært preget av å være et bondesamfunn. Samtidig er historien om Kapp Melkefabrikk og dens Viking melk ei historie som inkluderer en lang rekke viktige begivenheter, personer og årstall. Og ikke minst er denne historien ei fortelling om samspillet mellom et lite samfunn på Toten och en stor verden utenfor.

Kondensert melk er et produkt som først så dagens lys i USA på 1850-tallet. Amerikaneren Gail Borden fann ut at han kunne dampe in melka til bare $25 \%$ av det opprinnelige volum. Ved å koke i en lufttom kjele, altså under vakum, kunne innkokingen skje ved bare 30 graders varme. Den innkokte melka ble så tappet på blikkbokser som ble loddet igjen. For at melka skulle holde seg ble den imidlertid tilsatt sukker. Melka ble altså syltet og hermetisert. Kondensert melk ble et populært produkt. Ikke minst fordi det i siste del av 1800-tallet kom en voldsom økning i trafikken med handelsskip og det tidligere ikke hadde vært mulig å oppbevare melk over lang tid. På samme tid er det i ferd med å vokse fram store markeder for næringsmidler i stadig voksende storbyer.

I 1867 ble den første europeiske "syltede" melk produsert i Sveits, og i 1874 etablerte dansken Jess Thomsen den første norske fabrikken for sukret kondensert melk på Ha- mar. Thomsen hadde vært i Sveits og lært metodene. Geografisk sett er vi nå altså i Mjøsbygdene, og i ferd med å nærme oss Kapp.

Fabrikken på Hamar kom i produksjon i 1875, og kunne etter få års drift ta imot to mill. kg melk. I 1879 ble fabrikken overtatt av ei britisk/svensk investorgruppe og produksjonen ble utvidet til 7-8 mill. kilo årlig. Snart trengtes mer melk enn Hedmarksbøndene kunne produsere, og fabrikken kastet sine øyne på Toten.

Historia om hva som skjedde da oppkjøperne fra den engelske melkefabrikken i 1888 kom till Toten, er godt kjent. Storbonden Johannes Sund hadde invitert bygdas fremste menn til å møte oppkjøperne, og det ble servert velsmakende melkepunsj. Overrettssakfører Ulrik Graff var tilstede og noterte seg avtalene de kom fram til. Og etterhvert som melkepunsjen virket, ble forhandlingsklimaet bedre og bedre. Neste dag da Graff presenterte avtalen for oppkjøperne, hadde melkepunsjens effekt gått over. Graff mente de hadde engasjert ham til å være deres agent, slik at han skulle ha 1 øre pr. liter av melken han skaffet fabrikken. Dette ble avvist, - nei fra Hamar ville de gjøre avtaler med hver bonde og ikke gjennom noen mellommann.

Dette gjorde Graff sint, - ville ikke fabrikken kjøpe av ham, skulle de ikke få kjøpt noen melk på Toten i det hele tatt. Graff satte seg umiddelbart i kontakt med meieribestyrerne og bøndene som dengang foredlet melka i 12 små bygdemeierier spredt over hele Toten. Han sikret seg kjøpsavtaler på all melk ett år framover. Han sikret seg også alle ledige strandtomter runt Smørvika på samme måten. De som ønsket å kjøpe melk på Toten og frakte den på Mjøsa fra Kapp, måtte gjøre avtale med Graff. Men det som var en strategi for å få oppkjøperne fra Hamar til å gjen- 
nomføre sin opprinnelige tanke og samtidig sikre Graff en god profitt som mellommann, viste seg å slå feil. Hamarsingene og engelskmennene sa rett og slett nei, og fant det mer interessant å satse på bøndene i Østfold ved å bygge en ny stor fabrikk i Sandesund ved Sarpsborg.

Graff som hadde forespeilet totenbøndene store salgsinntekter av melkeproduksjonen, havnet nå i ei knipe. Eneste mulige løsning måtte rett og slett bli å sjøl starte opp en egen fabrikk. Graff satte igang arbeidet med å skaffe kapital. Det som imidlertid reddet ham, var den unge legen og mykologiforskeren Olav Johan Olsen, forresten også han fra Hamar, som satt i Kristiania og forsket på gjærsopper i ost. Nærmest ved et uhell fant han metoden for hvordan det kunne være mulig å konservere melk uten å tilsette sukker. Metoden var klar i 1889, samtidig med att Graff hadde startet organiseringen av sitt forretningsprosjekt. I oktober 1889 ble de endelige avtaler gjort mellom Graff og Olsen, - kong Oscar II tegnet seg for 10.000 kroner i aksjekapital, - de rikeste forrettningsfolkene $i$ landet fulgte etter og byggingen av fabrikken på Kapp startet. Etter problemer i driftsstarten var produksjonen endelig igang 7. februar 1891. Forsinkelsene tæret imidlertid på aksjekapitalen og etter 2 års drift var fabrikken i konkurs.

Produktet, usukret kondensert melk, var imidlertid godt. Og da driften startet opp igjen med ny aksjekapital i mars 1894 , kunne Olav Johan Olsen presentere melkeboksen med ny etikett: "Viking Melk". Året før hadde nemlig Magnus Andersen gjenomført ei vågal sjøreise tvers over Atlanterhavet i en nybygget kopi av Gokstadskipet. I alt 12 mann seilte $\mathrm{i}$ vikingeskipet over til verdensutstillingen i Chicago, og ombord hadde de selvsagt usukret kondensert melk fra Kapp.
Den nye etiketten for Viking-melk var laget av datidas kjente illustratører Andreas Bloch og Olaf Krohn.

Et varemerke var født. Viking Melk hadde ikke bare ett godt navn i 1890-tallets nasjonale bølge, men var også et godt produkt. Dette går ikke minst fram av det faktum at Viking Melk fortsatt produseres i Norge, 108 år etter de første boksene ble tappet på Kapp. Dette gjør Viking Melk til det eldste serieproduserte næringsmiddelet i Norge. Idag produseres den i Levanger av en årlig melkemengde på omlag 250.000 kilo.

Det ble en hovedsak å knytte Viking-melken til århundreskiftets store nasjonale helter som Fritjof Nansen og Roald Amundsen og til deres oppdagelsesreiser. Det var markedsføring som også var effektiv i de internasjonale markeder. Samtidig ble også Viking-melken kjent hos konkurrentene. En av disse var Nestlé-selskapet i Sveits. Deres argeste konkurrent Anglo-Swiss hadde fabrikker i flere land, og hadde i 1896 kjøpt fabrikkene på Hamar og Sandesund. Nå ønsket Nestlé å få fotfeste utenfor Sveits og kastet sine øyne på fabrikken på vestsida av Mjøsa. Etter forhandlinger høsten 1897 kunne så Nestlé overta sin første fabrikk utenfor Sveits. De betalte 720.000 kroner for alle aksjer i Kapp-fabrikken. For retten til å utnytte hans metode fikk Olav Johan Jonsson stilling som direktør, og økonomiske vilkår ellers som sikret ham økonomisk i si levetid foruten full frihet til å fortsette sitt vitenskapelige arbeid. Ikke dårlig for en 37-åring!

Nestlé sendte sine folk oppover fra Sveits og startet en vesentlig utbygging av fabrikken. De bygde også produksjonslokaler for sukkertilsatt melk. Produksjonen fra sept. 1900-sept. 1901 var 1,6 mill. kilo sukret melk og $800.000 \mathrm{~kg}$ usukret melk. I 1905 gikk 
92 Anglo-Swiss og Nestlé sammen. Istedet for å konkurrere med hverandre om pris og markeder, kunne de nå nyde godt av økende etterspørsel og store markedsandeler over hele verden.

Dette betød økt satsing på Kapp. Fabrikken var den største fabrikken selskapet hadde i Norge. Det ble utvidelser, og i 1910-1912 ble det gjort en stor utbygging. Det ble bygd et stort verksted for boksproduksjon, også beregnet på leveringer til de andre fabrikkene. Det ble bygd nytt pakkeri og det ble bygd en stor kontorbygning for selskapets sentrale bokføring. Bygget inneholdt også laboratorium for dr Sopp, lenge kaldt Sopp-Olsen, og som nå siden 1907 etter Bjørnstjerne Bjørnsons råd rett og slett tok Sopp till familienavn.

Fabrikken var nå inne i si glanstid. Arbeidsstyrken nådde 280 på det meste. Fabrikken kunne ta imot 60.000 liter melk om dagen fra hele Toten, men ved båttransport også fra Ringsaker og bygdene nord for Gjøvik. I 1915 tok Kapp imot 13 mill. kilo melk som den største melkekondenseringsfabrikk i landet.

"Kokeriet" skapte gode salgsinntekter for leverandørene og ringvirkninger ellers i lokalsamfunnene. Ikke minst innen fjøsstell og renslighet satte melkefabrikken nye standarder. Og for $\varnothing$. Toten som vertskommune utgjorde skatteinntektene fra fabrikken og arbeiderne i flere år omlag 25\% av kommunens samlede skatteinntekt.

Men toppen var nådd. Først kom det vansker skapte av verdenskrigen, og deretter av den generelle nedgangstid som virket sterkt inn på både markedet og kostnadene. Nestlé fant ut at Kappfabrikken hadde de høyeste kostnadene, og brukte nå nedleggelse av Kappfabrikken som trussel og våpen overfor det de oppfattet som urimelig høye lønnskrav fra arbeidernes organisasjoner.
"Nedleggelsen av fabrikken på Kapp skal også tjene til å vise funksjonærene og arbeiderne ved våre øvrige fabrikker at vi mener alvor med kravet om reduksjon av det altfor høye lønnsnivået. Vårt forslag om et nedslag på 25\% skal opprettholdes..." skriver Gustave Huguenin, konsernsjefens høyre hånd $\mathrm{i}$ Vevey (Sveits) i juli 1927. Da hadde allerede bemanningen på Kapp blitt redusert fra 240 til 100 gjennom de to foregående år.

Arbeiderne på fabrikken hadde dannet fagorganisasjon i 1912, og markert Kapp som bygdas "røde sentrum". I oppgangstider var foreningen nyttig, nå hadde en ikke noe å stille opp. Varaordfører C:A. Madsen uttaler i Oppland Arbeiderblad: "At fabrikken blir nedlagt er en ulykke både for bygden og den gamle, solide arbeidstok på Kap”. Og ulykke ble det - etterhvert som skatteinntektene uteble, og kommunen også måtte svare for lånegarantier gitt til arbeidernes boligfinansiering, gikk $\varnothing$. Toten kommune rett og slett konkurs. Kommunen måtte under administrasjon som vedvarte helt til midten av 1930-tallet.

Produksjonen av Vikingmelk ble innstilt 1 . juli 1928. En del av arbeiderne fikk arbeid på Hamar-fabrikken. Noen få kunne fortsette på Kapp ved laboratoriet og med produksjon av emmenthalerost, tørrmelk og barnemelk. Melkerasjonaliseringen under krigen satte imidlertid en stopper også for dette, slik at høsten 1942 opphørte den siste produksjon i Nestlés regi.

- Ur Kapp Melkefabrikk Utviklingsplan 1999-2005. 